Historic, Archive Document

Do not assume content reflects current scientific knowledge, policies, or practices. 


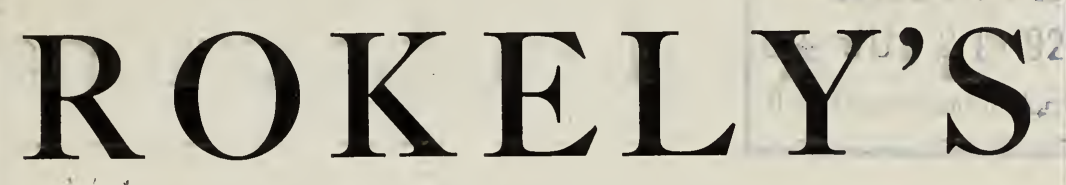

Descriptive Price

List of

\section{Small Fruit Plants}

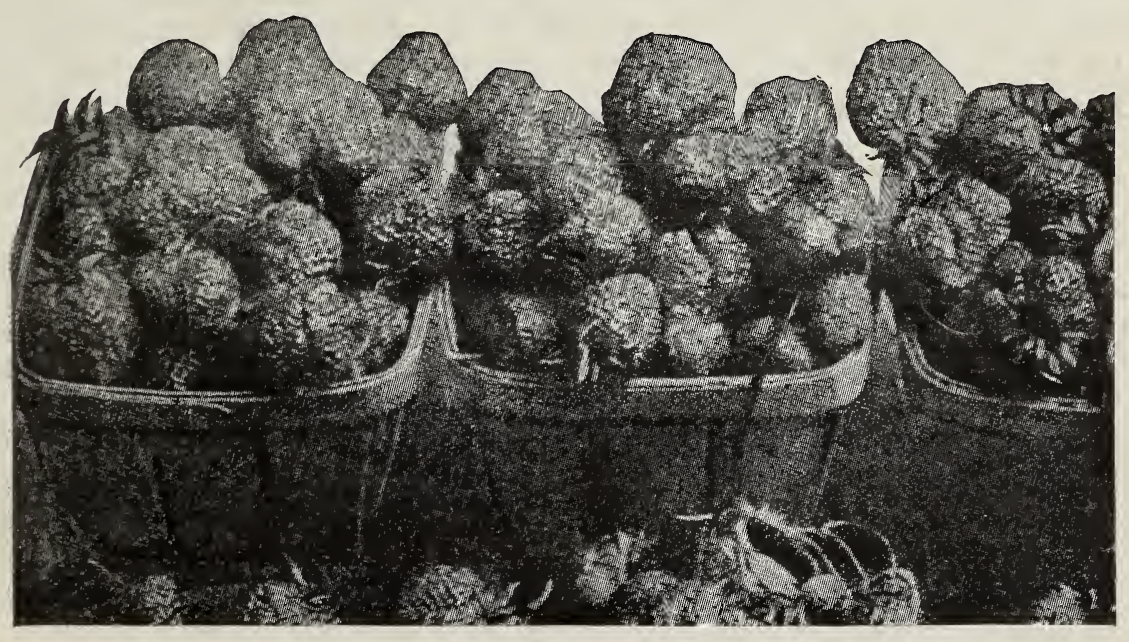

\section{The Strawberry \\ Is Our Specialty}

The J. N. Rokely Nurseries Bridg'man, Michigan 


\section{General Instructions}

Read Carefully

When writing, please sign your name plainly, being sure to give your postoffice. county and state.

Substitution: We will not substitute one variety for another without your prrmission unless order is received too late in the season to permit correstondence. In this case, some variety having the same season, sex and variety, would be substituted.

Terms: Cash with order or part cash and balance any time before shipinent is made. At our prices, we cannot afford to do a credit business. We give references as to our liability which any one is at liberty to investigate. For information regarding our standing and reliability, please refer to the Postmaster or Express Agent of Bridgman, or the Farmers \& Merchants Bank, Benton Harbor, Michigan. (In writing to any of the above, please enclose stamp for reply.)

How to Send Money: Chicago or New York Draft,

Express Money Order,

Postoffice Money Order,

Registered Mail.

Time to Order: Order early-the earlier the better. If anything more is needed it can be added later. If not prepared to send the full amount, send a part and the order will be tntered. The balance must be received beiore shipment is made. Orders are filled in rotation as received. We have at this writing several large o1 ders booked for spring shipment.

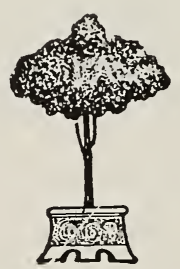

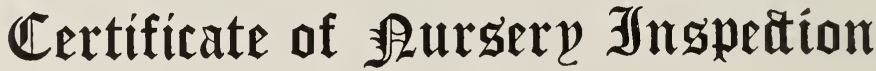

No. II 42 .

This is to certify that I have examined the nursery stock of J. N. Rokely of Bridgman, Michigan, and find it apparently free from dangerously contagious tree and plant diseases. This certificate to be void after July 3I, I9I2.

$$
\text { L. R. TAFT, }
$$

State Inspector of Nurseries and Orchards, Agricultural College, Michigan. 


\begin{tabular}{|l|l|l|}
\hline 1912 & Greeting & 1912 \\
\hline
\end{tabular}

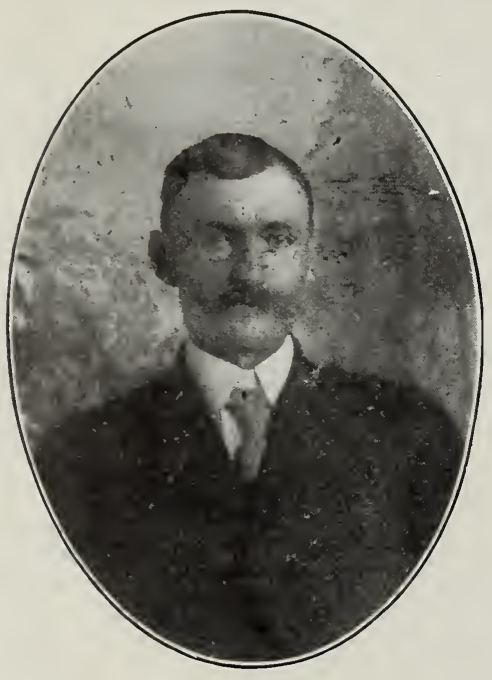

W

want to thank our many customers for their very liberal patronage of last season. Our sales were way beyond our expectations. We want to say to you that we appreciate your orders and we believe we have a large circle of satisfied customers judging from the many encouraging letters we have received from our patrons the past summer. We will continue to try to please each and every one of you in the future by supplying you with good, thrifty, well rooted plants at a price much less than most nurseries charge. We will continue our low prices of last year not making much change in our price list. In short we will treat you right. We want to say to those who have not favored us with an order, give us a chance and we will prove to you that we can furnish first-class stock at very low rates.

\section{OUR GUARANTEE}

We guarantee our stock to be first-class, true to name and packed to reach you in good growing condition (by Express). In case any stock is received that is not true to name or not as we represent it, we will replace free of charge with stock that is true to name or return the price paid for the same. Awaiting your favors which will receive my personal attention, I am

Very truly yours,

J. N. ROKELY.

\section{Strawberries}

The strawberry is our specialty. We have a fine stock of the best standard varieties which we are listing very low and will sell at prices quoted as long as stock lasts. Being situated in a section especially adapted to growing first-class plants, not being hampered with anything in the tree line, growing each variety in very large quantities and being satisfied with small profits, we can furnish firstclass stock at very low prices. Growing plants in large quantities we can give a discount on large bills (or orders). We have some varieties not listed here. If you want anything not listed, write us about it.

Varieties marked (P) are pistillate and should have about every third or fourth row set to some staminate variety for a fertilizer. Those marked (S) are staminate and good fertilizers. Set pistillate and staminate of the same season together.

All plants are trimmed, tied in bunches of 25 , and packed in plenty of damp packing moss.

Methods of Shipping: By express. This is the safest and all things considered, the cheapest way of shipping plants. Plants can be shipped 20 per cent less by express than merchandise. We have the United States Express Company.

By Freight: We ship considerable stock by freight but the difference in express and freight charges is so small that customers generally prefer express shipment.

Season of Shipping: We commence to ship the last of March or the first of April, according to season.

We set strawberry plants sixteen inches apart in the row and rows four feet apart. This takes about 7,000 plants to the acre. 


\section{Varieties of Strawberries}

Bederwood-(S). This variety was originated by Bederwood of Illinois. We have fruited it for many years and found it to be a very heavy bearer of goodsized fruit. Ripens early and produces an enormous quantity of fruit. One of our best money makers. $\$ 2.00$ per I,000.

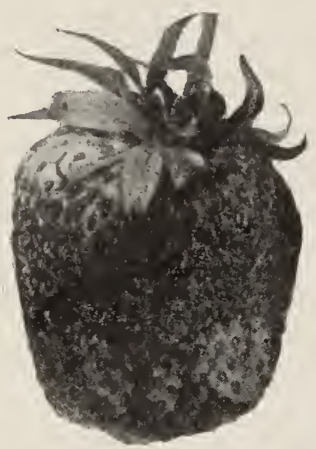

Aroma

Bubach-(P). This is one of the old standard varieties. Very popular with many growers. The plant is very large and showy. The berries are among the largest. A splendid berry for home use or nearby market. $\$ 3.00$ per I,000.

Bisel-(P). Plant is strong and able to carry its immense load of fruit to maturity. Berries are large, bright red and firm. A very popular variety. \$3.00 per I,000.

Aroma-(S). This is one of our very best late varieties; it cannot well be beaten for a late fancy berry or in quality of fruit, it ripens a few days ahead of Gandy and produces double the amount of fruit. I would recommend the Aroma for a late profitable variety. \$3.00 per I,00o.

Crescent-(Improved)-(P). Very productive. Stands neglect best of any. Plant small. Berries bright and attractive. Not very firm. Many growers consider this a very profitable berry for market. \$2.00 per I,000.

Enhance-(S). Medium early. A heavy bearer; firm; a good shipper. \$3.00 per 1,000 .

Gandy-(S). This is one of the leading late varieties with fruit growers all over the country. Fruit is large and firm, but does not yield as heavy as some. Resembles Aroma. A good variety. \$2.50 per I,000.

Glen Mary-(S). Large; medium late; fine flavor; vigorous and productive. Many growers here consider this the most profitable variety for market. \$3.00 per I,000.

Haverland-(P). Very productive; fruit large and fine. One of the most popular and well-tested varieties; color light; season, medium early. Considered throughout the country as a money maker. \$2.50 per I,000.

Senator Dunlap-(S). This berry is of the Warfield type; has a perfect blossom, is hardy, productive, a splendid keeper and is able to hold its own under any rough and tumble methods of cultivation to which it is likely to be suzjected.

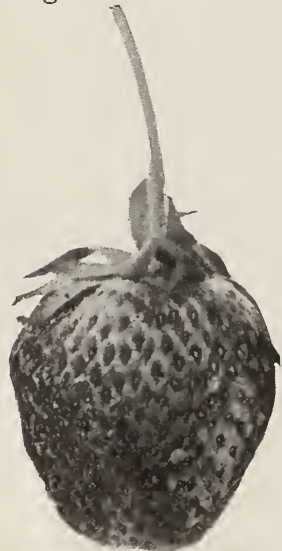

Sample Senato: Dunlap is a very hardy berry having good-sized even fruit of a very beautiful dark red color. It is a berry to grow for home use or market. Mr. Crawford says the Senator Dunlap is now the greatest all around variety ever introduced. Our stock of this variety is very large. They are great sellers. Try them. $\$ 2.00$ per I,000.

Uncle Jim-(S). Plants are large and free from rust. Berry is large, regular form and season is medium late. Uncle Jim is a comparatively new introduction. A very late variety. $\$ 3.00$ per $\mathrm{I}, 000$.

Warfield-(P). This is the one great standard variety that has been the leader all over the country for many years. Resembles Senator Dunlap. Good quality and fine flavor. All the growers are acquainted with the Warfield. \$2.00 per I,000.

Lovett-(S). One of the well-tested varieties. A great plant maker. Produces a quantity of fruit; firm; good quality but rather small in size. A good fertilizer for other varieties. $\$ 2.00$ per $\mathrm{I}, 000$. 

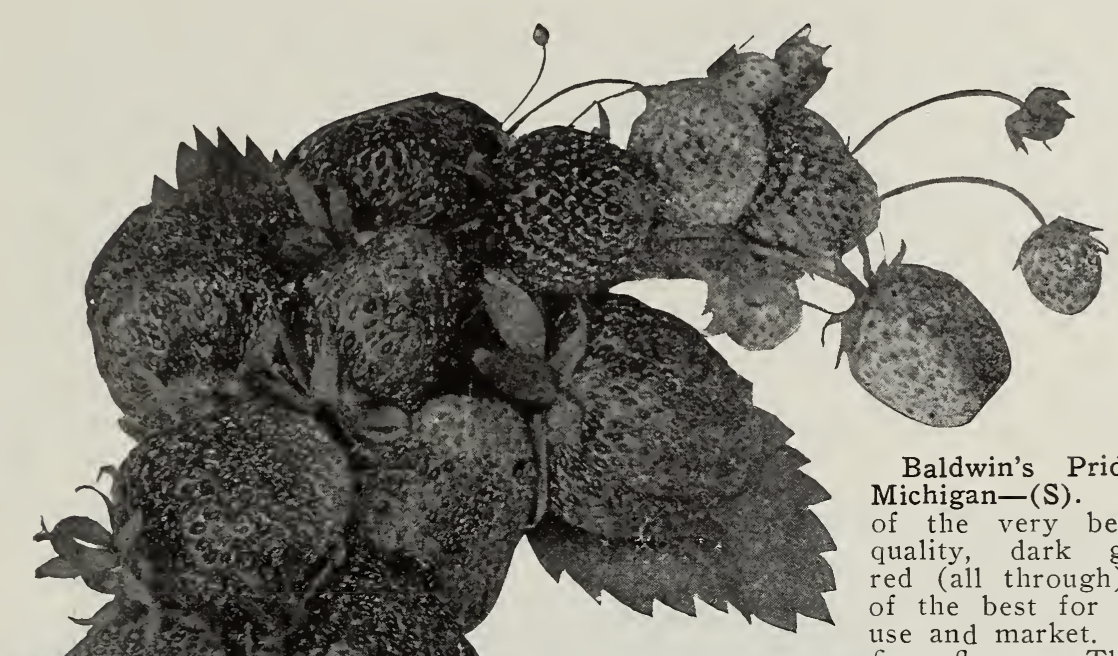

Baldwin's Pride of Michigan-(S). O n e of the very best in quality, dark glossy red (all through) one of the best for home use and market. Very fine flavor. The demand for this variety is very heavy. If you have never started with the Pride of Michigan, we advise you to order some now. It will please you. $\$ 3.00$ per 1,000 .

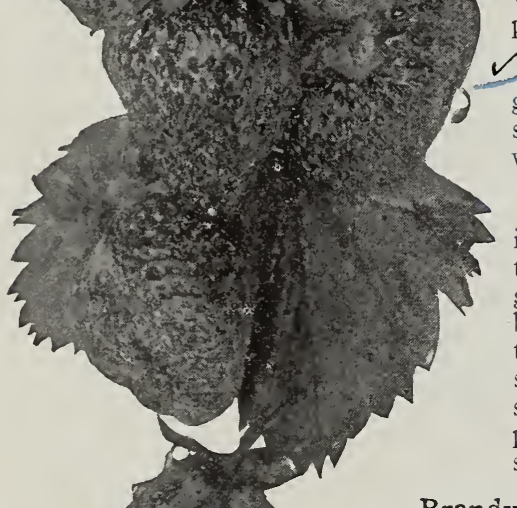

Steven's L a te Champion-(S). Plant growth extra good. The fruit is large and showy. Ripens with Aroma. A great favorite with some growers. $\$ 3.00$ per I,000.

August Luther-(S). This without a doubt is the best extra early strawberry under cultivation today. We would recommend $\mathrm{Au}$ gust Luther to all who want an extra early berry; ripens early and continues to bear till practically every berry reaches a good size; is very prolific. Fruit is verp uniform in shape and size. Plants are healthy and good plant makers. It succeeds best on rather light soil. \$2.00 per thousand.

Brandywine-(S). This is recommended to be one of large, good quality, good shape; firm and very productive. Dark red clear through; fine flavor and a very profitable market variety. $\$ 3.00$ per 1,000 .

Gibson-(S). This is recommended to be one of . he most profitable varieties under cultivation. Berries are large, dark red; a good shipper and very showy. We have not fruited this variety yet on our own grounds, but we believe it is a good one. $\$ 4.00$ per I,, 000 .

Norwood-(S). ' 1 'his is the genuine Norwood that every one talks so much about. We have not fruited this variety yet, but have a good supply of these plants to offer. Plants are very large and showy, they are said to be the largest strawberry grown; try them. \$10.00 per I,000.

Dollar Mark-(S). A rank grower and good plant maker, roots run deep and withstand drouth ana freezing. Berries large, perfectly formed, pointed and glossy; very solid and a good shipper. A good pollenizer. We believe this to be a very profitable variety and would advise vou to try some of them. $\$ 3.00$ per $\mathrm{I}, 000$.

Pocomoke-(S). One of the best varieties in existence. Not only for its enor- 
mous productiveness, but on account of its beauty, adaptability to all soils, its foliage, enduring the dry, hot weather, its large size, its deep color, its firmness and high flavor. The plant is a strong, robust grower with deep roots and lots of them. Perfect blossoms and is an enormous yielder of large red berries. It ripens evenly and is one of the best shippers yet introduced. Include a few thousand Pocomoke in your order. \$2.50 per I,000.

Sample-(P). Season late. The Sample is a great favorite with us. Very productive. We have fruited it for many years and we think it the best late strawberry we have (with the exception of Aroma). We have a fine stock of them. Fruit is very large and fine looking; dark red all through. One trait of the Sample is its perfect system of coloring a certain percentage of its fruit each day until the season is over and the bright red is evenly distributed all over the berry. \$3.00 per 1,000 .

We have other varieties of strawberries not listed. If you want anything not listed here-write us about it.

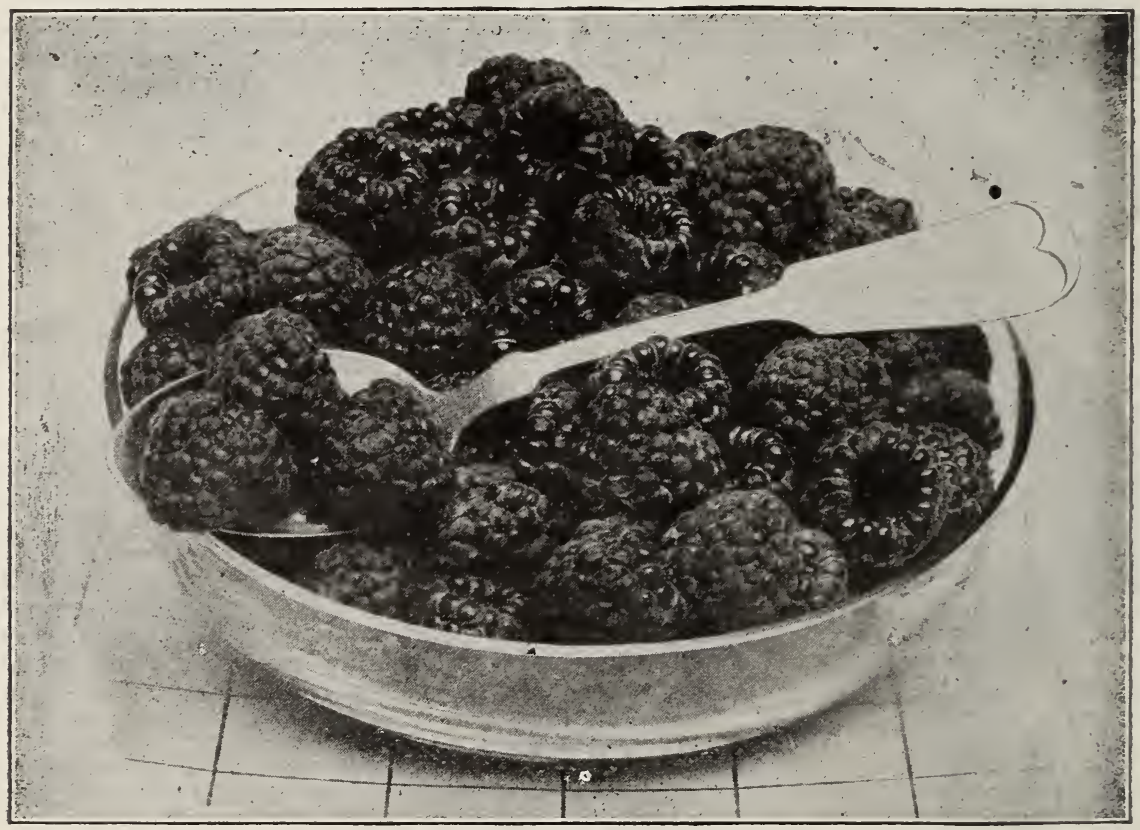

Cumberland

\section{Black Raspberries}

$2=$ at 100 rates and 250 at $I, 000$ rates.

\section{INSTRUCTIONS}

Kaspherrics will grow and do well on any ground that will produce good field crops. Soil must be comparatively dry or well drained. We generally set raspberrics about jour feet apart in the row and the rows six feet apart.

Cumberland-The largest black raspberry in existence. This raspberry is placed upu:! the market with the full assurance that it is the most profitable marhet rariety yet known, because of its immense size, firmness and great productiveness. Cimberland is very hardy, having withstood a temperature of sixteen 
degrees below zero without injury. Extra productive. Fruit is jet black and of fine quality. Ripens before Gregg. $\$ 7.00$ per I,000.

Gregg-Fruit very fine and covered with bloom. Gregg has been the leading market variety all over the country. A good all-around late black cap. In quality they are hard to beat. They are large and productive. $\$ 7.00$ per $\mathrm{I}, 000$.

Conrath-This is a very profitable variety; very productive; fruit large; good flavor; firm; nearly coal black and parts readily from core. Although early, it has a long season and holds its size well to the end. $\$ 6.00$ per 1,000 .

Eureka-An extra fine black cap in every way. It is of extra large size; extra quality and extra early. Eureka is a money maker. \$7.00 per I,000.

Kansas-This variety is a general favorite with growers all over the country. Ripens just after Soughegan. Firm, handsome and of the best quality. Bush a strong grower; stands drouth and cold. Very productive. It is about as large as Gregg. Strong, healthy canes. $\$ 6.00$ per I,00o.

Early Ohio-A good extra early variety A favorite with some growers. A good yielder of medium sized fruit. \$6.00 per I,ooo.

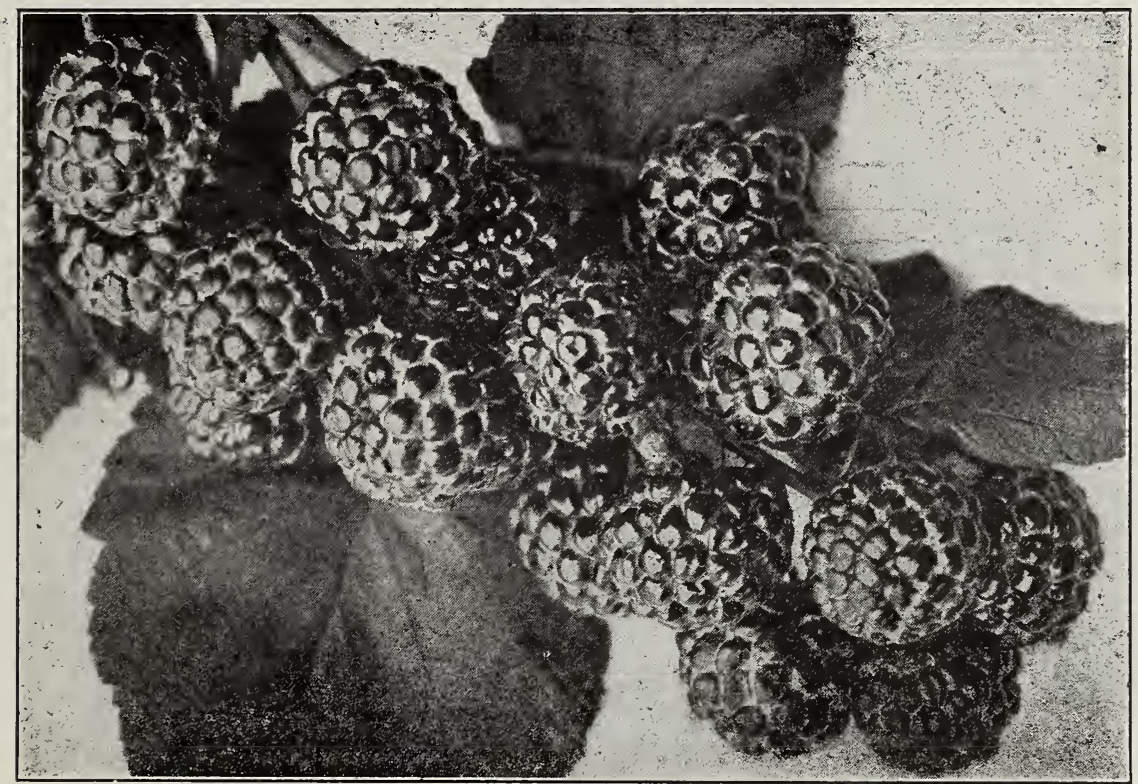

Haymaker

\section{Purple Raspberries}

Columbian (Purple Cap)-The Columbian is a variety of the Shaffer type of remarkable vigor and productiveness. It is very hardy and propagates from tips. Fruit very large, often an inch in diameter. Color dark red bordering on purple. Price, $\$ 10.00$ per I,000.

The Haymaker (Purple Cap)_Not so dark as the Columbian or Shaffer and much firmer than either of those varieties. Never crumbles, and stands up well in shipping. It is a berry to grow for home use or market. Try a few of the Haymaker or Columbian and we believe you will be pleased with them. Price, \$10.00 per I,000. 


\section{Red Raspberries}

Cuthbert-Leading late variety, all over the country. A very rank grower. Very productive. Fruit large and of good quality. If you want a good, all round late red raspberry, plant the Cuthdert. Price, $\$ 5.50$ per $\mathrm{I}, 000$.

Miller-(Red). Early; very hardy and does not winter kill. The Miller is for an early berry what the Cuthbert is for a late one. The very best shipping qualities.

Price, $\$ 5.00$ per 1,000 .

King-This is a new red raspberry of beatiful color; firm and having a high quality of fruit. Very early, Large and attractive bright red berries. Several of our best growers consider this the best of the early red raspberries.

$\$ 6.00$ per 1,000 .

Thompson's Early-This variety is very profitable. The fruit is of extra good quality and ripens very early bringing top prices. These are being set extensively in this locality for the Chicago market.

$\$ 7.00$ per I,000.

\section{Blackberries}

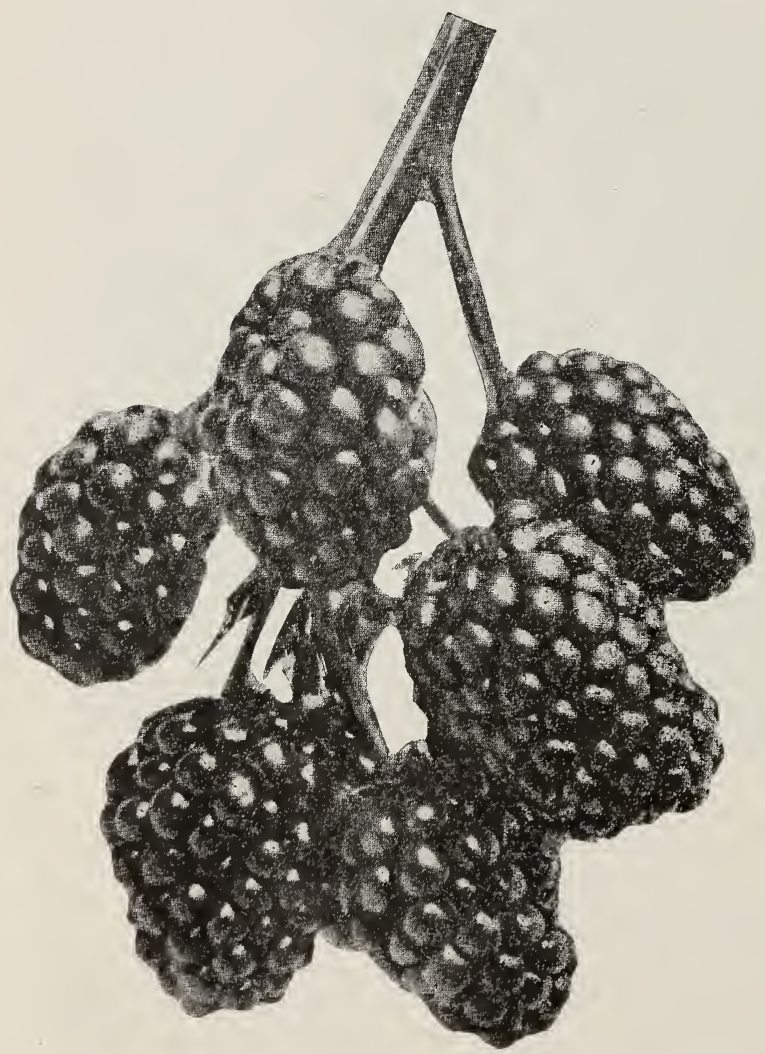

Wilson-This is the best blackberry under cultivation to day. The fruit is the largest, produces double the bushels per acre and the best quality of any. Holds its color well after picking. It is the best shipper there is. Very profitable in spite of the fact that the Wilson requires protection in Michigan. There are about ten acres of the Wilson variety grown to one acre of any other variety of blackberry. It always sells at a premium over the other varieties on the Chicago market and the quotations on them are always the highest. The berry is jet black and holds its color after picking-never turning red. The Wilson is a money maker.

Price, $\$ 6.00$ per I,000.

Wilson Jr.-Practically the same as the Wilson but ripens a few days earlier. Price, $\$ 6.00$ per I,000.

Eldorado- $T$ h is berry is as hardy as the Snyder, twice as large and better qualitp. It has never been known to winter kill even in Northern Michigan and Wisconsin. Very profitable as it needs no protection in winter.

Price, $\$ 10.00$ per $\mathrm{I}, 000$.

This ends our list of varieties and we believe it is enough fur the ordinary grower. If you should decide to place your order with us we promise you good thrifty plants, well-rooted and true to name. 


\section{J. D. ROKELY，Bridgman, Mich.}

Name

Post Office

County

Express Office

Freight Station

Express Co.

Amount Enclosed

$\$$

Ship by

DO NOT WRITE YOUR LETTER ON THIS SHEET

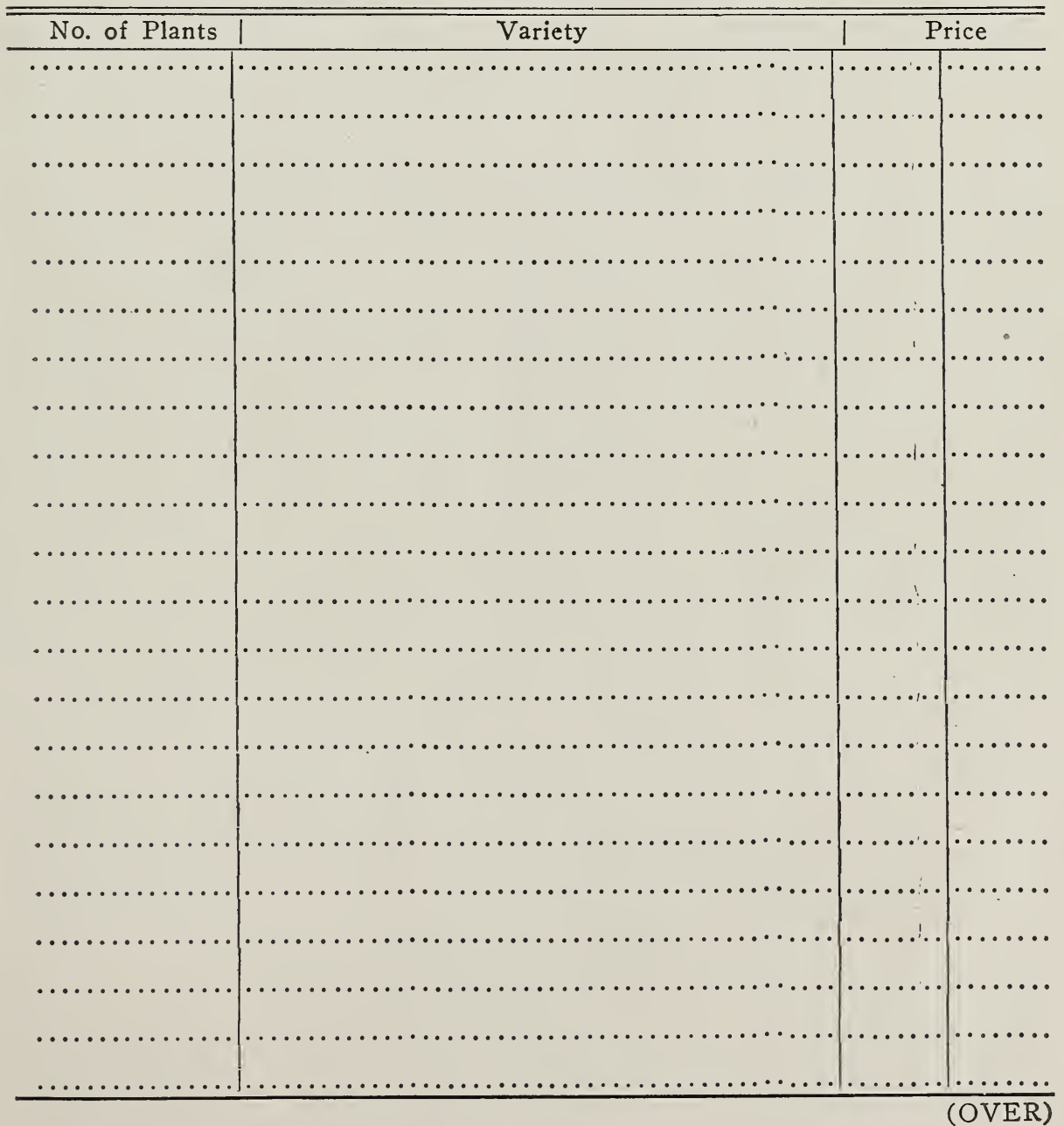


If you are sure some of your neighbors would appreciate our Catalogue, will you please write their names and addresses below? We will inolude a few extra plants for your trouble. 


\section{How to Prepare the Soil}

One important and advantageous feature of the strawberry business not always appreciated is the fact that the strawberry in any ordinary soil yields large harvests of fruit. As to fertilizer, we prefer stable manure over anything else. If the soil is strong enough to produce a large crop of corn or potatoes, it will grow a line crop of strawberries without the application of any fertilizer.

The best time to apply the manure is in the winter, just when the soil tiller has ample time at his command in which to do the work. It should be spread erenly over the entire surface, so that it will mulch the ground. siot only does it enrich the ground when thus applied, but it also keeps the soil from puddling, ar:di in the spring it will plow up loose and mellow as a garden. After the plowing is dore, go civer the field with harrow or disc until the soil and manure are thoroughly mixed together. It should be pulverized finely to the depth of the plowing.

If your soil is sandy, or loose black soil, it should be rolled firmly, but if it be clay or stiff black soil, roll it only enough to crush the clods. If the harrow follows directly after the breaking plow, before the clods have time to dry out and become hard, the clods will crumble and it will be unnecessary to roll at all. We recommend that this course be followed if you have but one team; plow awhile and iiien harrow thoroughly the newly plowed ground.

If for any reason you cannot haul manure during the winter, then wait until spririg, plow your ground as outlined above, and set the plants. After this is done you may spread the fine manure between the rows and the cultivator will mix the manure into the soil. We often have manured our plants in this way, and the results are excellent. In fact, it is an ideal way.

In some localities stable manure cannot be had, and in such cases commercial fertilizers may be used. A fertilizer best adapted to the needs of the strawberry should contain the three principal plant-food ingredients in about the following proportions: Nitrogen, 3 per cent; Potassium, 9 fer cent; Phosphorus, 7 per cent.

A commercial fertilizer should be applied and thoroughly worked into the soil before the plants are set.

\section{PRICE LIST OF STRAWBERRY PLANTS}

\begin{tabular}{|c|c|c|c|c|}
\hline $\mathrm{Pe}$ & 100 & & Per roo & 000 \\
\hline (S) & .40 & \$2.00'Dollar Mark, (S) & .50 & 3.00 \\
\hline & .50 & 3.oo Haverland, (P) & .50 & 2.5 \\
\hline vood, $(\mathrm{S})$ & .40 & 2.oolovett, (S) & .40 & 2.00 \\
\hline $\begin{array}{l}\text { h, }(\mathrm{P}) \\
\text { ywine, }\end{array}$ & .50 & 3.00 Norwood, (S) & 1.25 & I \\
\hline$(\mathrm{P})$ & $\begin{array}{l}.50 \\
.50\end{array}$ & $\begin{array}{l}\text { 3.00 Pride of Michi } \\
\text { 3.00Pocomoke, (S) }\end{array}$ & $\begin{array}{l}.50 \\
.50\end{array}$ & 2.00 \\
\hline $\mathrm{nt}, \quad(\mathrm{P})$ & .40 & 2.ooSenator Dunlap, (S) & .40 & 2.00 \\
\hline$(\mathrm{P})$ & .50 & 3.00 teven's Late Champ. (S) & .50 & 3.00 \\
\hline & .60 & ple, (P) & .50 & 3.00 \\
\hline (S) & .40 & 2.50Uncle Jim, (S) & .50 & 3.00 \\
\hline Iary, (S) & .50 & 3.0o Warfield, (P) & .40 & 2 \\
\hline
\end{tabular}

We sell 25 at 100 rates and 250 at 1,000 rates. Write for special prices on larger lots. We cant, of cource. oive a diccount if you want several thousand plants. Varieties marked (P) are Pistillate and must have staminate varieties set every third or fourth row. Those marked (S) are Staminate and fertilize themselves. They can be set 1 large patches alone with best results. We advise all to place their orders early before our stock is broken. All inquiries promptly answered.

We have long distance telephone in our office.

Very truly yours,

J. N. Rokely.

\begin{tabular}{|c|c|c|c|c|c|}
\hline $\mathrm{Pe}$ & $\begin{array}{l}\mathrm{C}_{\mathrm{L}}^{\mathrm{L}} \\
\mathrm{I00}\end{array}$ & I.000 & Per & I00 & $\mathrm{I}, \mathrm{OOO}$ \\
\hline & $\$ 0.75$ & $\$ 5.50$ & Gregg Black & .90 & 7.00 \\
\hline & .75 & 5.00 & Eureka Black & .90 & 7.00 \\
\hline I's early red & .75 & 5.00 & Early Ohio Black & .90 & 6.00 \\
\hline $\mathrm{E}$ & .90 & 7.00 & Cumberland purple & 1.00 & 10.00 \\
\hline 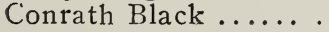 & .90 & 6.00 & Haymaker purple & $\mathrm{I} .00$ & I0.0 \\
\hline
\end{tabular}

PRICE LIST OF BLACKBERRY PLANTS

$\begin{array}{rrr}\text { Per } & \text { roo } \\ . . .6 & .80\end{array}$

$\mathrm{I}, \mathrm{000}$

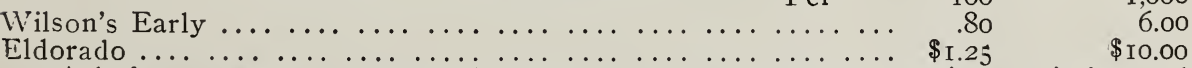

Ask for prices on Currant, Gooseberry and Grape plants stating varieties and amount wanted. 


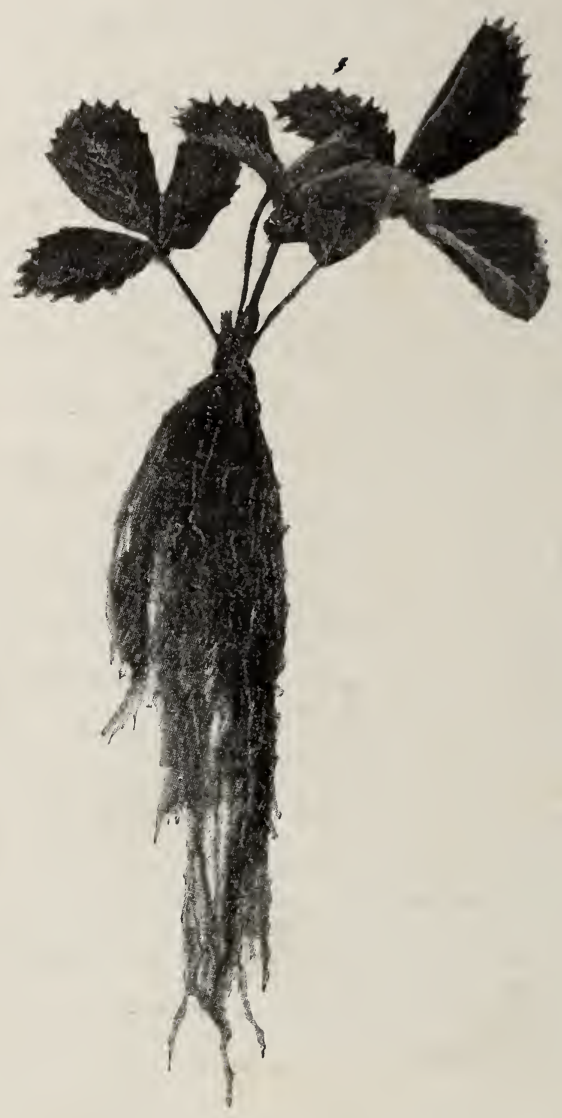

Printed by the Benton Review Shop, Fowler, Indiana 